\title{
MAPS AVAILABLE
}

(bibliographic guide prepared courtesy of Dr. J. Gravesteijn, BRGM, France)

\section{CENTRAL AMERICA}

\section{General Literature}

Weyl, R., Die Geologie Mittelamerikas, Berlin : Gebrüder Borntraeger, 1961226 p. (Beiträge zur Regionalen Geologie der Erde, 1)

With supplement in : Zentralblatt für Geologie and Paläontologie, Teil I, 1970, Heft 7/8.

Weyl, R., El desarollo paleogeografico de América Central: Bol. Ass. Mex. Geol. Petrol., Mexico D.F, 25, 1974, p. 376424.

\section{Maps}

Geological Atlas of the World - 1:10000000 - Paris : UNESCO - Sheet 3 - 1974 .

Geologic map of North America - 1:5000 000 - Washington, D.C. : U.S. Geol. Surv., 1965, 2 sheets.

Tectonic map of North America - 5000000 - Washington, D.C. : U.S. Geol. Surv., 1969, 2 sheets.

Stratigraphic Atlas of North and Central America, prepared by the Exploration Department of Shell Oil Company: Princeton University Press, Princeton, 1975, $272 \mathrm{p}$.

Petroleum developments and generalized geology of Central and South America, Los Angeles (9800 SO Sepulveda Boul.): Hunger Map Book, 1968, 119 p. (Atlas of uncol. maps).

Geologic map of Central America - 1:1 000000 In : Roberts, J.R., Irving, E.M., Mineral deposits of Central America: U.S. Geol. Surv., Bull., 1034, 1957.

Mapa metalogenético de America Central - 1:2000000 Guatemala (Av. La Reforma 4-47, Zona 10); Instituto Centroamericano de Investigacion y Tecnologia Industrial (ICAITI), 1969, 2 sheets, with 58 p. text: Publ. Geol. ICAITI, No. 3 , 1970.

\section{BELIZE}

\section{General Literature}

Dixon, C.G., Geology of Southern British Honduras with notes on adjacent areas, Belize : Government Printer, 1955, 85 p. Incl. geol. map, scale 1285120 .

Flores, G., Geology of Northern British Honduras: Bull. Amer. Ass. Petrol. Geol., Vol. 36, No. 2, 1952, p. 404-413.

Ower, L.H., Geology of British Honduras: J. Geol., Vol. 36, No. 6, 1928, p. 498-509.

\section{Maps}

\section{General Maps}

British Honduras. Carte géologique, 1:1000 000 approx. (uncol. map) In : Hoffstetter, R., British Honduras.

- Lexique stratigraphique international, Vol. V, Amérique Latine, fasc. 2a, Amerique Centrale, Paris, CNRS, 1960.

Mapa Geologico de la Republica de Guatemala, 1:500 000 Guatemala : Instituto Geografico Nacional, 1970, 4 sheets, Incl. Belize.

\section{Miscellaneous Maps}

Bateson, J.H., New interpretation of geology of Maya Mountains, British Honduras: Bull. Amer. Ass. Petrol. Geol., Vol. 56, No. 5, 1972, p. 956-963. Incl. uncol. geol. map, scale 1:250 000 approx. (Map area on Sketch Map)

Hall, H.S., Bateson, J.H., Late paleozoic lavas in Mayas Mountains, British Honduras, and their possible regional significance: Bull. Amer. Ass. Petrol. Geol., Vol. 56, No. 5, 1972, p. 950-956. Incl. uncol. geol. map, scale 1:250 000 approx. (Map area on Sketch Map)
Geological map of the Maya Mountains, Belize, 1:130000 (approx.) In : Bateson, H.S. - The geology of the Maya Mountains, Belize: Inst. Geol. Sc. Nat. Env. Res. Council, Overseas Memoir, No. 3, 1977. (Map area on Sketch Map)

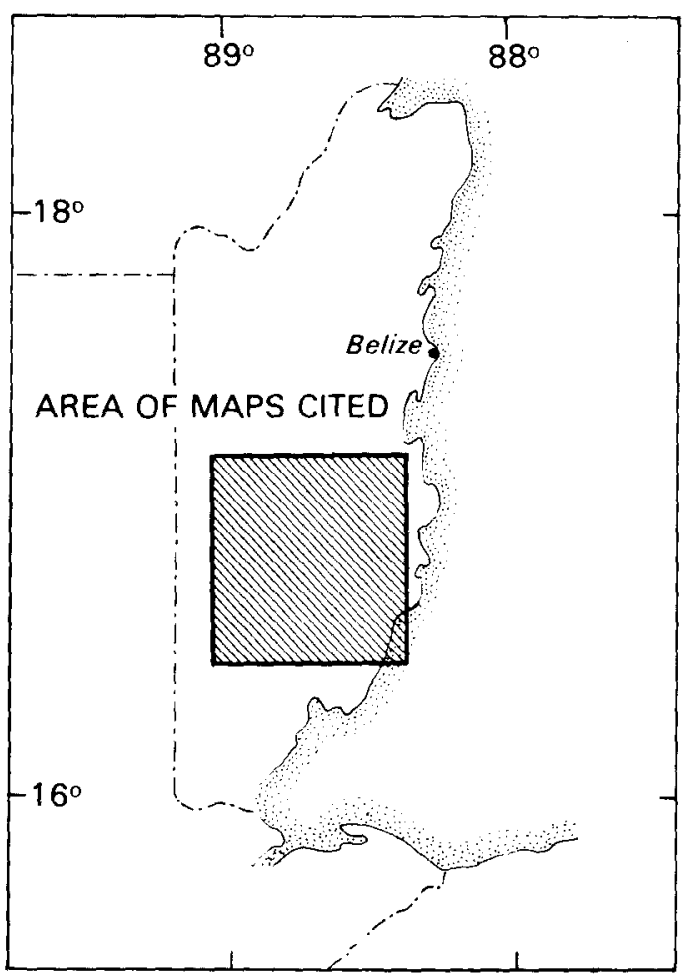

\section{GUATEMALA}

\section{General Literature}

Bibliografia geologica de Guatemala, America Central (harta 1965), Guatemala : La Edicion, 1966,81 p.

Boris, S.B., A summary of the geology of Guatemala: Publ. Geol. ICAITI Vol. 2, 1969, p. 76-80.

\section{Maps}

\section{General Maps}

Mapa geologico de la Republica de Guatemala, 1:500000 Guatemala : Instituto Geografico Nacional, 1970, 4 sheets.

\section{Systematic Mapping}

Mapa geologico general de Guatemala, 1:250 000 Guatemala : Instituto Geografico Nacional (See Index Map).

Mapa geologico de Guatemala, 1:50 000 Guatemala : Instituto Geografico Nacional (See Index Map). Miscellaneous Maps

Williams, H., Volcanic history of the Guatemalan Highlands: Univ. Calif. Publ. Geol. Sc., Vol. 38, No. 1, 1960, p. 1-64, Incl. geol. map, scale 1:580 000 (Map area 1 on Sketch Map)

Williams, H., McBirney, A.R., Dengo, G., Geologic reconnaissance of Southeastern Guatemala; Univ. Calif. Publ. Geol. Sc., Vol. 50, 1964, p. 1-56, Incl. geol. map, scale 1:250 000. (Map area 2 on Sketch Map)

Walper, J.L., Geology of Coban - Purulha area, Alta Verapaz, Guatemala: Bull. Amer. Ass. Petrol. Geol., Vol. 44, No. 8, 1960, p. 1273-1315, Incl. geol. map, scale 1:150 000. (Map area 3 on Sketch Map) 


\section{MAPS AV AILABLE (Continued)}

Index Map: Mapa Geológico de Guatemala, 1:50 000

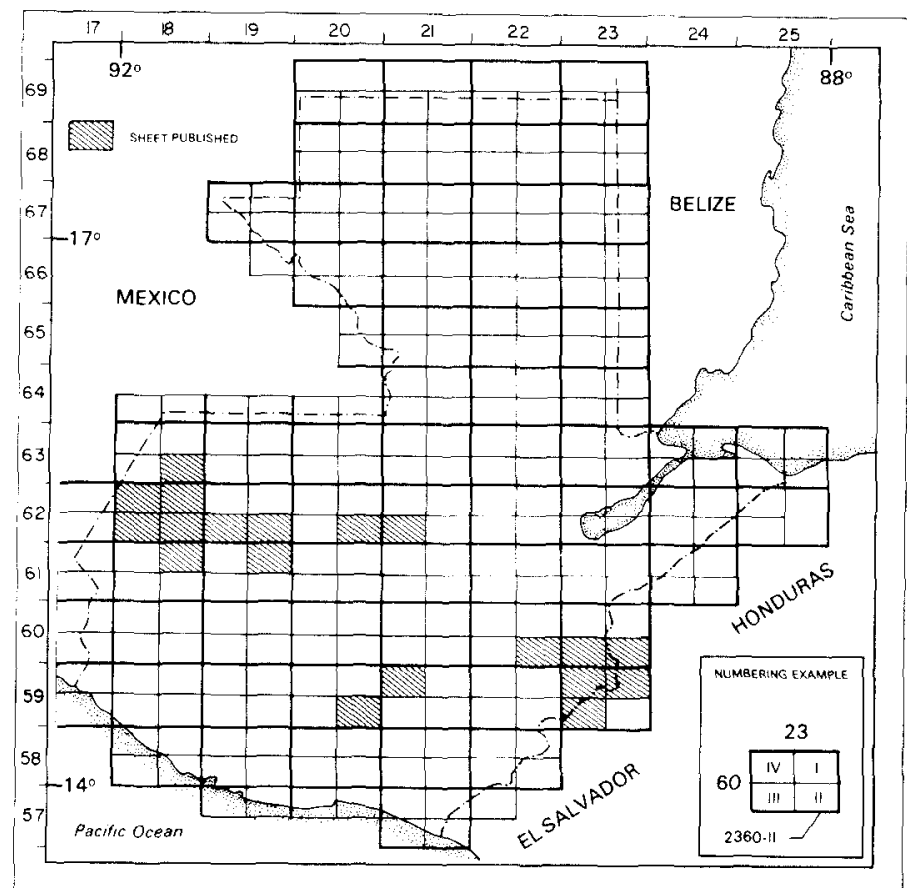

Bonis, S., Reconocimiento geologico del Cinturon plegado de Alta Verapaz, Guatemala: Inst. Geogr. Nac., Bol. Geol., No. 5, 1967, Incl. geol. map, scale 1:125000. (Map area 4 on Sketch Map)

Geologische Ubersichtskarte Baja Verapaz und Südteil der Alta Verapaz (Guatemala) = Mapa Geológico General Baja Verapaz y parte sur de la Alta Verapaz (Guatemala), $1: 125000$

Hannover : Bundesanstalt für Bodenforschung, 1971, 1 sheet (Map area 5 on Sketch Map)

McBirney, A.R., Geology of a part of the Central Guatemalan Cordillera: Univ. Calif. Publ. Geol. Sc., Vol. 38, No. 4, 1960 , p. 117-231, incl. geol. map, scale 1:75 000 (Map area 6 on Sketch Map)

Sheets Published:

1861-IG Santa Barbara (1971)

1862-IG Todos Santos Cuchumatan (1976)

1862-IIG San Sebastian Huehuetenango (1970)

1862-IIIG Cuilco (1968)

1862-IVG La Democracia (1967)

1863-IIG San Miguel Acatan (1975)

1961-IG Sacapulas (1975)

1962-IIG Nebaj (1975)

1962-IIIG Chiantla (1968)

2059-IIG Amatitlan (1974)

2062-IIG Tiritibol (1976)

2159-IV G San José Pinula (1975)

2162-IIIG Cobàn (1976)

2260-llG Chiquimula (1966)

Out of print:

2359-IG Chanmagua (1966)

2359-IIIG Cerro Montecristo (1966)

2359-IVG Esquipulas (1966)

2360-IIG Timushán (1966)

2360-IIIG Jocotan (1966)
Sketch Map: Miscellaneous Maps - Guatemala

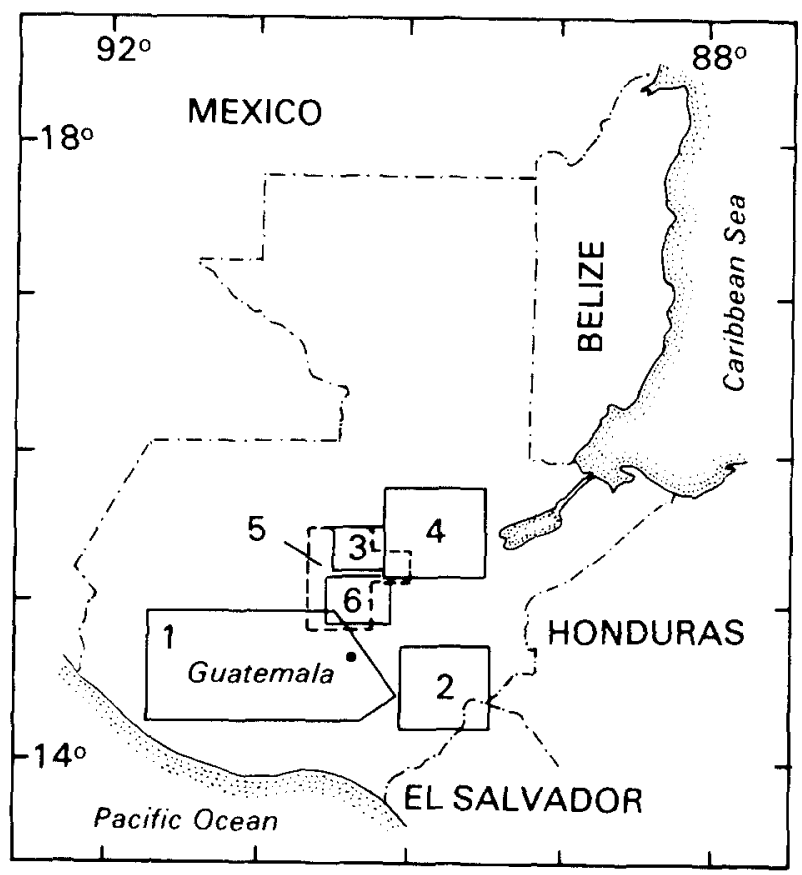

Index Map: Mapa Geologico General de Guatemala, 1:250 000
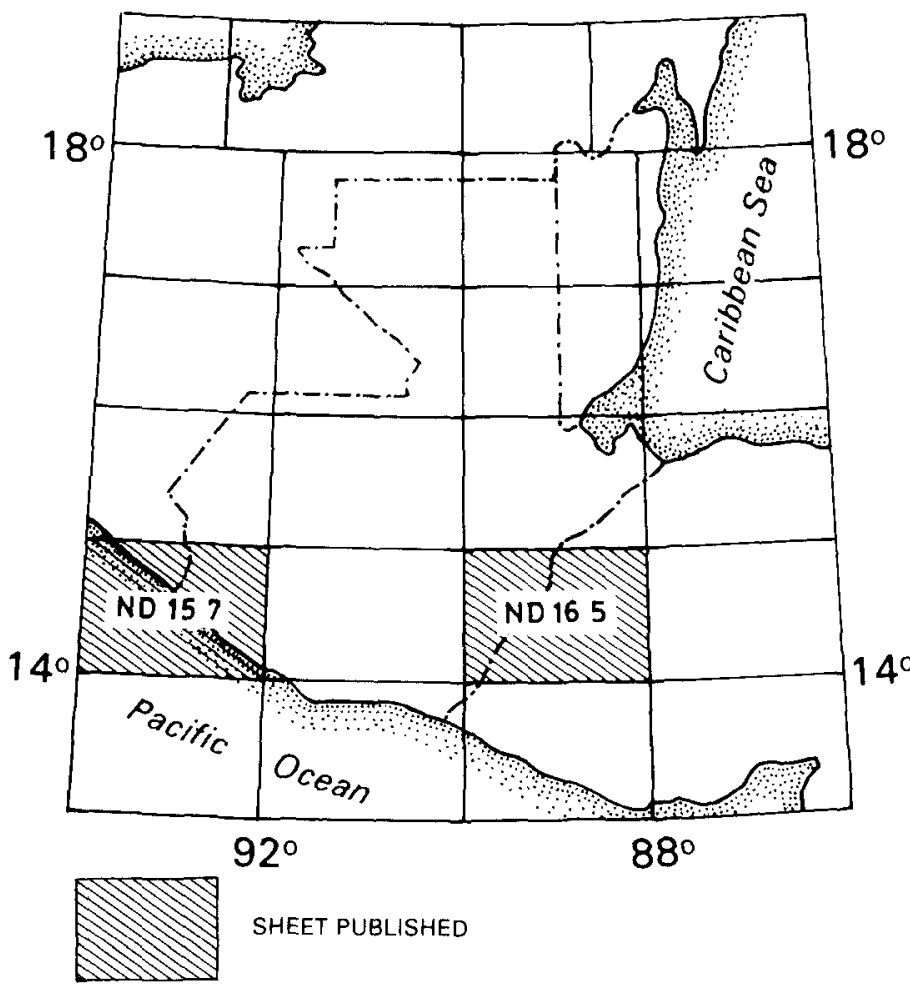

SHEET PUBLISHED

Order address: Instituto Geografico Nacional, Avenida Las Américas 5-76, zona 13, Guatemala City, Guatemala 

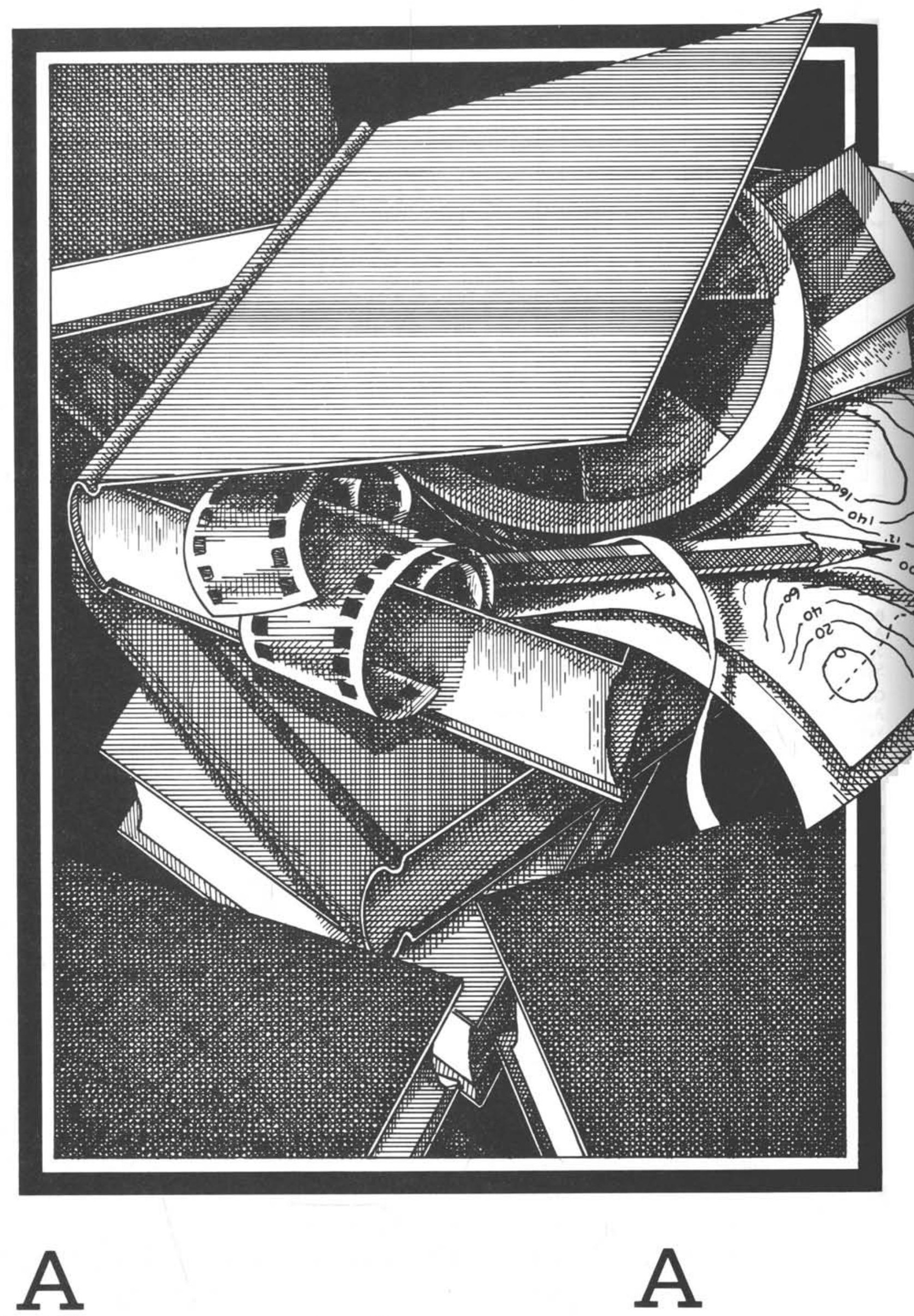
The AAPG Bookstore sells more than just books • We have quite a selection of other materials for the practicing professional geologist - Maps, 35mm photographic slides, slide/audiotape presentations, and, a few video shows are also available $\bullet$ All are tailored to the needs of our professional membership The AAPG is committed to serving the needs of its members by providing publications and programs that would otherwise not be available to an individual - That's one reason why our members are among the best trained professionals in the world $\bullet$ To find out more about the AAPG, write to our Membership Services Department, American Association of Petroleum Geologists, P.O. Box 979, Tulsa, Oklahoma 74101, U.S.A.

- Take a look at the list of publications and audiovisual programs featured in our new 1980 bookstore catalog For a copy of the catalog, write to the AAPG Bookstore, P.O. Box 979, Tulsa, Oklahoma 74101, U.S.A., or write to Brown's Geological Information Services, Ltd., 160 North Gower Street, London, NW1 2ND, England. 


\title{
NOW AVAILABLE COAL DEPOSTTS \\ ORIGIN, EVOLUTION, AND PRESENT CHARACTERISTICS
}

\author{
J. H. TATSCH
}

This is no ordinary book on coal deposits. Nor does it simply detail the locations and gross characteristics of the Earth's coal deposits. Rather, it shows how coal deposits have originated, have evolved, and have become emplaced into their present environments in accordance with a single, long-lived, deep-seated mechanism that has been operating within the Earth during the 4.6 billion years that the Earth is believed to have been in existence, with particular attention to the Carboniferous, Permian, Cretaceous, and Tertiary periods. The mechanism used is the "tectonospheric Earth model," which has been described in the book, THE EARTH'S TECTONOSPHERE (1972), and used as the basis for the books, MINERAL DEPOSITS (1973), PETROLEUM DEPOSITS (1974), GOLD DEPOSITS (1975), COPPER DEPOSITS (1975), URANIUM DEPOSITS (1976), GEOTHERMAL DEPOSITS (1976) and EARTHQUAKES (1977).

Chapter headings: 1 , The origin of coal; 2 , The global distribution patterns of coal deposits; 3 , The geometrical, mechanical, thermal, and chemical behavior of the Earth during the past 4.6 billion years; 4, Plate tectonics, omniductive processes, and seismotectonomagmatic belts; 5 , Precambrian seismotectonomagmatic belts and the associated coal deposits; 6, Paleozoic seismotectonomagmatic belts and the associated coal deposits; 7, Mesozoic seismotectonomagmatic belts and the associated coal deposits; 8, Cenozoic seismotectonomagmatic belts and the associated coal deposits; 9, The present distribution of coal deposits as a function of the Earth's behavior during the past one billion years; 10, The Tectonospheric Earth Model as a supplementary tool in the exploration for coal deposits. Appendix: The Tectonospheric Earth Model: a new concept.

This book, composed almost entirely of proprietary material, summarizes the results of an independent research project undertaken to determine the most probable geometrical, mechanical, thermal, and chemical aspects of the origin, evolution, and present characteristics of the Earth's coal deposits. Because of its proprietary nature, very little of this material has been published in journals. Nor is it expected that very much of it will be offered for publication other than in book form. This approach, we feel, permits the reader to gain a better perspective of the subject matter presented.

May be ordered directly from the address shown below or from book dealers in all parts of the world. Hard cover, $6 \times 9$ inches, 590 pages. Table of contents, line drawings, index, maps, references. 156 ISBN:0-912890-13-4. LC:76-28096. 1980

\section{Tatsch Associates}

120 THUNDER ROAD

SUDBURY, MASSACHUSETTS 01776

U.S.A. 